\title{
Consumer Online Purchase Decision and its Influencers in Uttrakhand: A Factor Analysis Method
}

\author{
Rupa Khanna, Gunjan Awal, Shipra Gupta
}

\begin{abstract}
Research on various factors affecting web based purchasing behaviour has garnered a lot of attention over the last decade. This is largely because of tremendous growth of online shopping in India. As per a Google India report titled "Year in Search" there will be more than 650 million Indians on the web. Along these lines, Owing to this enormous development, the given examination centers around dismembering factors influencing client's electronic purchasing choice in chosen locale of Garhwal division of Uttrakhand. The information for this investigation was accumulated utilizing direct overview with the assistance of an organized poll. The respondents having earlier web based shopping experience were chosen from various locale of Garhwal Division of Uttrakhand. A 550 example outline was picked for interest, yet just 500 respondents restored the filled poll inside multi month of discharging. All factors for the survey were distinguished utilizing the writing on web based shopping. The information was broke down utilizing SPSS. The measurable systems of examination that were utilized for the given investigation incorporate Factor Analysis and ANOVA for distinguishing the variables influencing web based buying method just as the effect of those components on definite buying choice. The consequences of this investigation show that significantly 5 variables influence the internet buying choice to be specific Convenience, Security and Privacy, Product Related Factors, Service related elements, Website related components, Personal elements.Thus, The aftereffects of this examination give an important reference to the e-advertisers to comprehend the elements impacting shopper online buy choice.
\end{abstract}

Keywords: Online shopping, Decision-making process Influence, Uttrakhand, Factor Analysis

\section{INTRODUCTION}

In the year 2018, Google India turned out with a broad report titled, 'Year in Search' which hurls light into the way in which Indian eats up content. Starting at 2017, India's web clients were evaluated somewhat north of 400 million. Today, that number is more like 450 million. While that number establishes under $30 \%$ of our complete populace, it is the second biggest online market after China - and it is just developing. By 2020, the "Year in Search" India report assesses in excess of 650 million Indians will be on the web. That is twofold the number of inhabitants in the United States.

Revised Manuscript Received on August 10, 2019.

Rupa Khanna, Professor, Department of Commerce, Graphic Era Deemed to be University, Dehradun, India.

Gunjan Awal, Department of Commerce, Graphic Era Deemed to be University, Dehradun, India.

Shipra Gupta, Professor, Department of Commerce, Graphic Era Hill University, Dehradun, India.
Consistently, an ever increasing number of Indians are finding the web and incorporating it into their day by day lives - to search for data, amusement, answers and everything in the middle. Thus, considering such sustainable amount of growth in Indian E-Commerce market, it becomes necessary to consider the affecting elements of online purchaser practices, to improve those components that advance online buyer buying and change the ominous variables accepting the satisfaction of client as the start point and outrageous target of publicizing rehearses. Just by giving incredible things, reasonable expenses, and finish benefits, and satisfying customers' needs, can an online market player secure more clients, increase bits of the pie, and make unprecedented focus abilities and advantages.

\section{REVIEW OF LITERATURE}

(Srivatsan, Vemulamanda and Venkatramana 2018) talked about different highlights and parts of E-Commerce by considering the pace of development of eight significant web based business organizations working in India from their very commencement to their till date working and along these lines examine the most recent patterns of $\mathrm{E}$ Commerce in Indian economy. (Kukreti, Richa, and Singh 2018) attempted to discover the variables that significantly affect a person's purchasing conduct while making an online buy. Utilizing exploratory factor investigation he found that four factors that significantly affect web based purchasing conduct are client benefits, quick financial and verified online buy, pattern with innovation and simple availability.(Rahman et al ,2018) led an examination on an example of 160 respondents from Dhaka city in Bangladesh in order to comprehend the direct of online customers .the outcomes show that buyers shop online to spare time, and for open blends of things and associations. (Zhao 2015) Both male and female both have a practically identical sort of lead towards getting a charge out of and detesting factors; they like home development office and loathing powerlessness to contact and feel the product.(Wang and $\mathrm{Qu}$ 2017) attempted to think about the effect of Internet Shopping merchandise exchange on online buyer buy conduct utilizing writing survey. There are three unique components of merchandise exchange return cost, return time limit and endeavors.( Limpo, Lita \& Meryana 2015). The customer's discernment towards merchandise exchange can be portrayed utilizing three measurements, for example, saw hazard, saw quality and saw reasonableness. 
(Fortes and Rita 2016) endeavored to examine the effect of protection worries on a person's expectation to make online buys. He found that there exists a connection among protection and online buy expectation by means of the association among security and saw hazard, trust, saw helpfulness, saw usability and saw social control. (Kumar and Victor 2014) conducted a study on students in Lucknow aged between 18 to 25 years to find out the factors influencing online customer satisfaction. (Agarwal and Bhuvaneswari 2016) conducted an empirical study on working class customers of Uttrakhand state about their frame of mind towards Internet shopping. They conducted the study on 300 respondents belonging to middle income class. The results of the study indicate that males show more attraction towards online shopping as compared to females. Moreover, there exists a direct connection among literacy level and frame of mind towards Internet shopping. (Katawetawaraks, Chayapa \& Wang 2013). The outcomes show that web architecture, security, item assortment and value, item quality, conveyance administration, data quality, installment technique, eadministration quality emphatically impact online consumer loyalty. (Sawant and Malviya 2014) led an examination on the youth of Indore city to study the determinants of youth's perception towards online shopping.( Harahap, \& Amanah. 2018). The study identified six factors such as web portal quality, Pre and post sales services, online interface usability, security and other strategy, clear payment and conveyance, trust on web portal, that affect perception of younger generation in Indore city.

\section{RESEARCH OBJECTIVES}

The Main Objective of the assessment is to explore and dismember factors influencing client's online purchasing choice in chosen locale of Garhwal division of Uttrakhand. The Sub Objectives of the examination are to break down socio-segment status of online customers, to recognize kinds of item classes in web based shopping that are ordinarily bought by individuals, to decide if saw security and protection of online exchange affect respondents' web based buying choice.

\section{RESEARCH METHODOLOGY}

4.1 The Investigation: This examination is exploratory in nature and attempted to give a comprehension of the components prompting internet shopping. The examination is for the most part dependent on essential information used to investigate factors impacting customer's online buy choice. Time of the examination was from July, 2019 to November, 2019. The investigation contained people living in chosen locale of Garhwal division who belong to the agegroup of 18-40 with prior online purchase experience.

4.2 The Sample: The sample of the investigation was comprised of 500 respondents from chosen regions of Garhwal Division.

4.3 The Tools for Data Collection: A self organized survey was utilized to gather information. The underlying section of the study included requests concerning measurement profile of respondents and Internet use affinities for the respondents, for instance, how visit they scrutinize Internet, how much time they spent, what sort of things the respondents purchase on the web and what sum do they spend on online shopping. The second bit of the survey consolidated a self - sorted out scale that was used to assemble fundamental data. The 32 close finished things of the scale depended on five point Likert scale (Strongly Agree -5 to Strongly Disagree -1 ) and used to quantify 'factors influencing customer's online buy choice. The unwavering quality of the scale was discovered utilizing Cronbach's Alpha.

4.4 The Tools for Data Analysis: The investigation of gathered information was finished by Statistical Package for Social Science (SPSS). The gathered information was then exposed to Principal Component Method of Factor Analysis utilizing Varimax Rotation to extract factors. To study about the effect of investigated factors, ANOVA was used.

\section{DATA ANALYSIS}

The study results are sorted out as pursues. In the main area, the statistic profile of the respondents is displayed. The second segment shows the consequences of ANOVA and Chi-Square Test.

Table 1: Statistic Attributes of Respondents

\begin{tabular}{|c|c|c|c|}
\hline Variables & $\begin{array}{c}\text { Classification of } \\
\text { Variables }\end{array}$ & Frequency & Percentage (\%) \\
\hline \multirow{4}{*}{ Age-Group } & $18-25$ & 78 & 15.6 \\
\hline & 26-35 & 161 & 32.2 \\
\hline & $36-45$ & 195 & 39 \\
\hline & 45 and Above & 66 & 13.2 \\
\hline \multirow{2}{*}{ Gender } & Male & 261 & 52.2 \\
\hline & Female & 239 & 47.8 \\
\hline \multirow{2}{*}{$\begin{array}{l}\text { Marital } \\
\text { Status }\end{array}$} & Married & 339 & 67.8 \\
\hline & Unmarried & 161 & 32.2 \\
\hline \multirow{2}{*}{$\begin{array}{l}\text { Educational } \\
\text { Qualification }\end{array}$} & Professional Degree & 83 & 16.6 \\
\hline & Post Graduation & 155 & 31 \\
\hline
\end{tabular}


International Journal of Innovative Technology and Exploring Engineering (IJITEE) ISSN: 2278-3075, Volume-8 Issue-10S2, August 2019

Source: Primary Data

\begin{tabular}{|c|c|c|c|} 
& Under Graduation & 178 & 35.6 \\
\cline { 2 - 4 } & Diploma & 39 & 7.8 \\
\cline { 2 - 4 } & Schooling & 45 & 9 \\
\hline \multirow{4}{*}{$\begin{array}{c}\text { Average } \\
\text { monthly } \\
\text { family } \\
\text { income }\end{array}$} & Rs. 20,000 and below & 65 & 13 \\
\cline { 2 - 4 } & $\mathbf{2 0 , 0 0 0 - 3 0 , 0 0 0}$ & 111 & 22.2 \\
\cline { 2 - 4 } & $\mathbf{3 0 , 0 0 0 - 4 0 , 0 0 0}$ & 139 & 27.8 \\
\hline \multirow{3}{*}{ Occupation } & Above 40,000 & 185 & 37 \\
\cline { 2 - 4 } & Business & 61 & 12.2 \\
\cline { 2 - 4 } & Service & 300 & 60 \\
\cline { 2 - 4 } & Housewife & 45 & 9 \\
\cline { 2 - 4 } & Student & 94 & 18.8 \\
\hline
\end{tabular}

Table 2-Internet Usage

\begin{tabular}{|c|c|c|c|}
\hline Variables & Classification of Variables & Frequency & Percentage \\
\hline \multirow{4}{*}{$\begin{array}{l}\text { Place of } \\
\text { Accessing } \\
\text { Internet }\end{array}$} & Home & 285 & 57 \\
\hline & Office & 200 & 40 \\
\hline & Cyber Cafe & 10 & 2 \\
\hline & other & 5 & 1 \\
\hline \multirow{5}{*}{$\begin{array}{c}\text { Time } \\
\text { spent on } \\
\text { Internet } \\
\text { on Daily } \\
\text { Basis }\end{array}$} & 1 hour and below & 122 & 24.4 \\
\hline & 1-3 Hours & 189 & 37.8 \\
\hline & 3-5 Hours & 78 & 15.6 \\
\hline & 5-7 Hours & 72 & 14.4 \\
\hline & 7 Hours and Above & 39 & 7.8 \\
\hline \multirow{7}{*}{$\begin{array}{c}\text { Purpose } \\
\text { of } \\
\text { Internet } \\
\text { Usage }\end{array}$} & Entertainment & 120 & 24 \\
\hline & Product Search and & 128 & 25.6 \\
\hline & Information & & \\
\hline & E-mail/Chatting & 85 & 17 \\
\hline & $\begin{array}{c}\text { Program/Music } \\
\text { Downloading }\end{array}$ & 100 & 20 \\
\hline & Online Shopping & 160 & 32 \\
\hline & All of the Above & 57 & 11.4 \\
\hline \multirow{4}{*}{$\begin{array}{c}\text { Ability to } \\
\text { use } \\
\text { Internet }\end{array}$} & Not Skillful & 89 & $\mathbf{1 7 . 8}$ \\
\hline & Somewhat Skillful & 105 & 21 \\
\hline & Skillful & 189 & 37.8 \\
\hline & Very Skillful & 117 & 23.4 \\
\hline
\end{tabular}

Source: Primary Data

Table3-Online Shopping Behavior

\begin{tabular}{|c|c|c|c|}
\hline Variables & $\begin{array}{l}\text { Classification of } \\
\text { Variables }\end{array}$ & Frequency & Percentage $(\%)$ \\
\hline \multirow{5}{*}{$\begin{array}{c}\text { Product } \\
\text { Purchased } \\
\text { Online }\end{array}$} & Electronics & 163 & 32.6 \\
\hline & Books & 85 & 17 \\
\hline & $\begin{array}{l}\text { Computer } \\
\text { Accessories }\end{array}$ & 118 & 23.6 \\
\hline & Grocery & 70 & 14 \\
\hline & $\begin{array}{l}\text { Fashion and } \\
\text { Jewellery }\end{array}$ & 180 & 36 \\
\hline
\end{tabular}


Consumer Online Purchase Decision and its Influencers in Uttrakhand: A Factor Analysis Method

\begin{tabular}{|c|c|c|c|}
\hline & All of the Above & 85 & 17 \\
\hline \multirow{4}{*}{$\begin{array}{c}\text { Mode of } \\
\text { Payment used } \\
\text { for } \\
\text { online purchase }\end{array}$} & $\begin{array}{l}\text { Debit Card/Credit } \\
\text { Card }\end{array}$ & 128 & 25.6 \\
\hline & Net Banking & 85 & 17 \\
\hline & Cash on Delivery & 211 & 42.2 \\
\hline & Any of these & 145 & 29 \\
\hline \multirow[t]{4}{*}{$\begin{array}{l}\text { Frequency of } \\
\text { Online Shopping }\end{array}$} & $\begin{array}{l}\text { Rarely(once per } \\
\text { month) }\end{array}$ & 255 & 51 \\
\hline & $\begin{array}{l}\text { Seldom(1 to } 3 \\
\text { times per month) }\end{array}$ & 115 & 23 \\
\hline & $\begin{array}{l}\text { Often( Once per } \\
\text { week) }\end{array}$ & 61 & 12.2 \\
\hline & $\begin{array}{l}\text { Very often(More } \\
\text { than once ) }\end{array}$ & 69 & 13.8 \\
\hline \multirow{4}{*}{$\begin{array}{c}\text { Average } \\
\text { Amount spent } \\
\text { on } \\
\text { online shopping } \\
\text { per month }\end{array}$} & Rs500-1000 & 185 & 37 \\
\hline & $1000-5000$ & 172 & 34.4 \\
\hline & $5000-10000$ & 50 & 10 \\
\hline & 10000 and Above & 93 & 18.6 \\
\hline \multirow{4}{*}{$\begin{array}{l}\text { No. of products } \\
\text { purchased } \\
\text { during last } 6 \\
\text { months }\end{array}$} & None & 89 & 17.8 \\
\hline & One to Four & 239 & 47.8 \\
\hline & Five to Seven & 95 & 19 \\
\hline & Seven and Above & 77 & 15.4 \\
\hline \multirow{4}{*}{$\begin{array}{l}\text { Frequency of } \\
\text { abandoning } \\
\text { shopping cart }\end{array}$} & Never & 178 & 35.6 \\
\hline & Rarely & 150 & 30 \\
\hline & Often & 111 & 22.2 \\
\hline & Very often & 61 & 12.2 \\
\hline \multirow{3}{*}{$\begin{array}{l}\text { Internet Usage } \\
\text { behavior pattern }\end{array}$} & Visitor & 155 & 31 \\
\hline & Browser & 139 & 27.8 \\
\hline & Internet Buyer & 206 & 41.2 \\
\hline
\end{tabular}

\section{Source: Primary Data}

\subsection{Tools of Data Analysis}

\section{1) Reliability Testing: Cronbach's Alpha}

Cronbach's Alpha is planned as a proportion of interior consistency of things in the survey. It fluctuates somewhere in the range of zero and one. The closer alpha is to one, the more noteworthy the inward consistency of the things in the poll. All out number of inquiries or things in the survey is 32 trying factors or LIKERT scale factors. Thus "N" of things in the underneath Cronbach's Alpha test is 32 .

Table 4: Results of Reliability Analysis

\begin{tabular}{|c|c|}
\hline Cronbach's Alpha & No. of Items \\
\hline 0.804 & 32 \\
\hline
\end{tabular}

\section{Source: Primary Data}

Inference: Cronbach's alpha test was performed to check the unwavering quality of inquiries or things and it brought about a general score of 0.804 showing inner consistency of the things.

\section{2) Factor Analysis}

To investigate factors affecting online purchasing decision, respondents were provided with a list of statements and were asked for to stamp their understanding or conflict with every one of these announcements on a 5 point Likert scale running from 1 for firmly Disagree to 5 for Strongly Agree. The subsequent reactions were factor broke down. Bartlett's Test of sphericity $(p<0.001)$ and KMO Sampling Adequacy test $(0.707)$ showed that information were suitable for factor analysis. Essential Component Analysis with Varimax Rotation while holding Eigen Values more prominent than 1 and factor loadings of 0.40 or more noteworthy diminished 32 items into 6 Factors. The factor arrangement showed that right around 88 percent of the fluctuation was clarified by six factors. 
International Journal of Innovative Technology and Exploring Engineering (IJITEE)

ISSN: 2278-3075, Volume-8 Issue-10S2, August 2019

Table 5-Factors affecting Online Purchasing Decision: Exploratory Factor Analysis

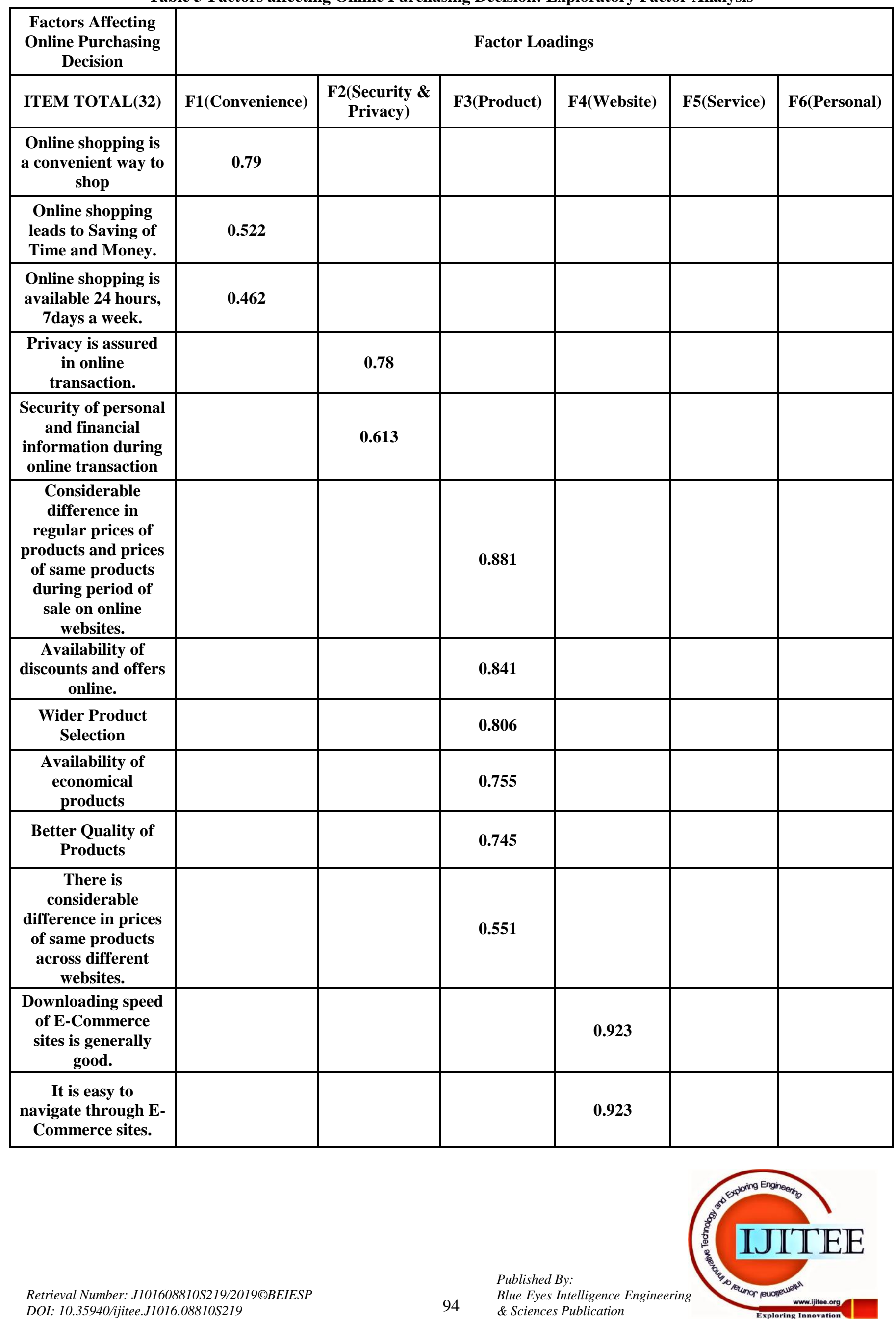


Consumer Online Purchase Decision and its Influencers in Uttrakhand: A Factor Analysis Method

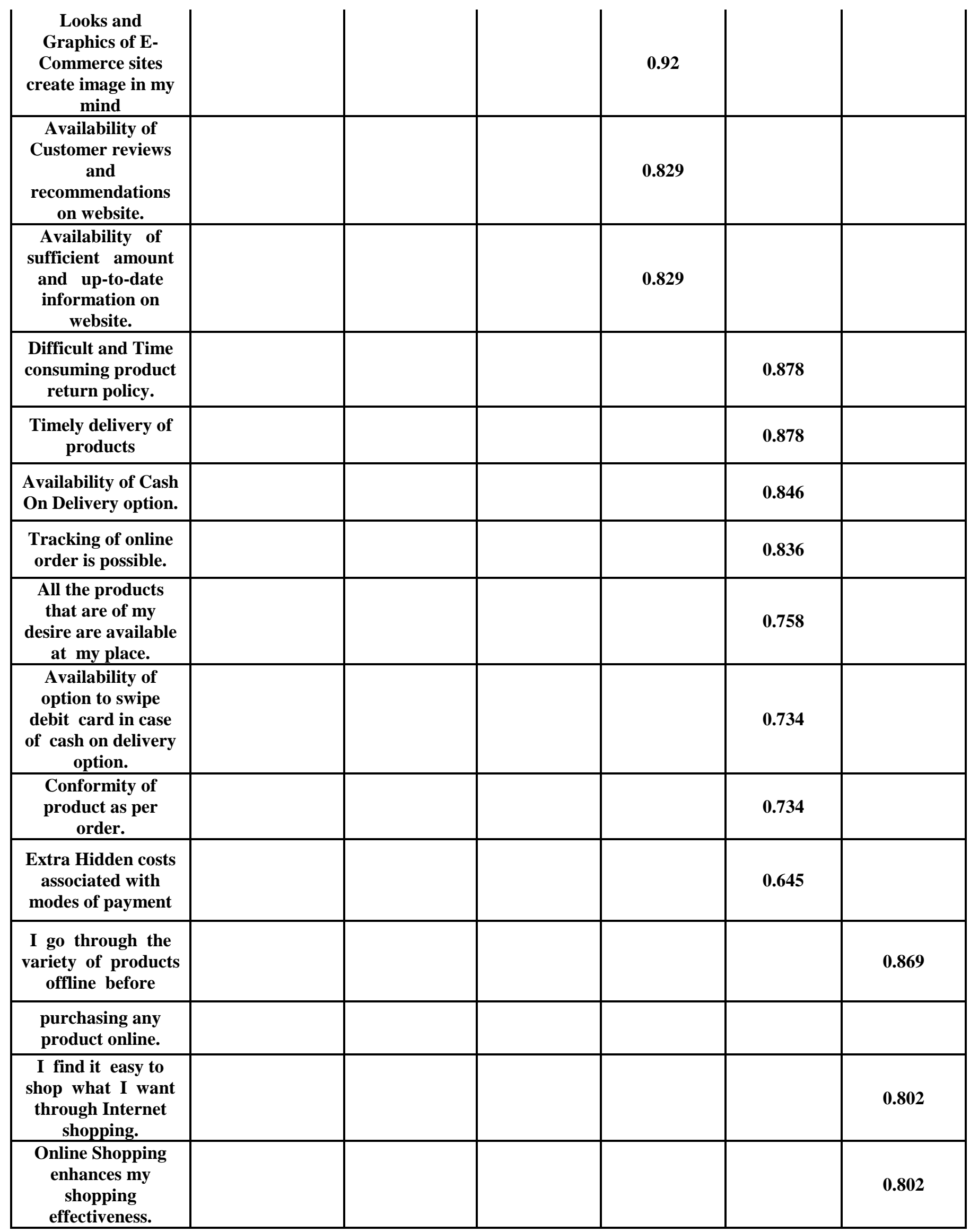




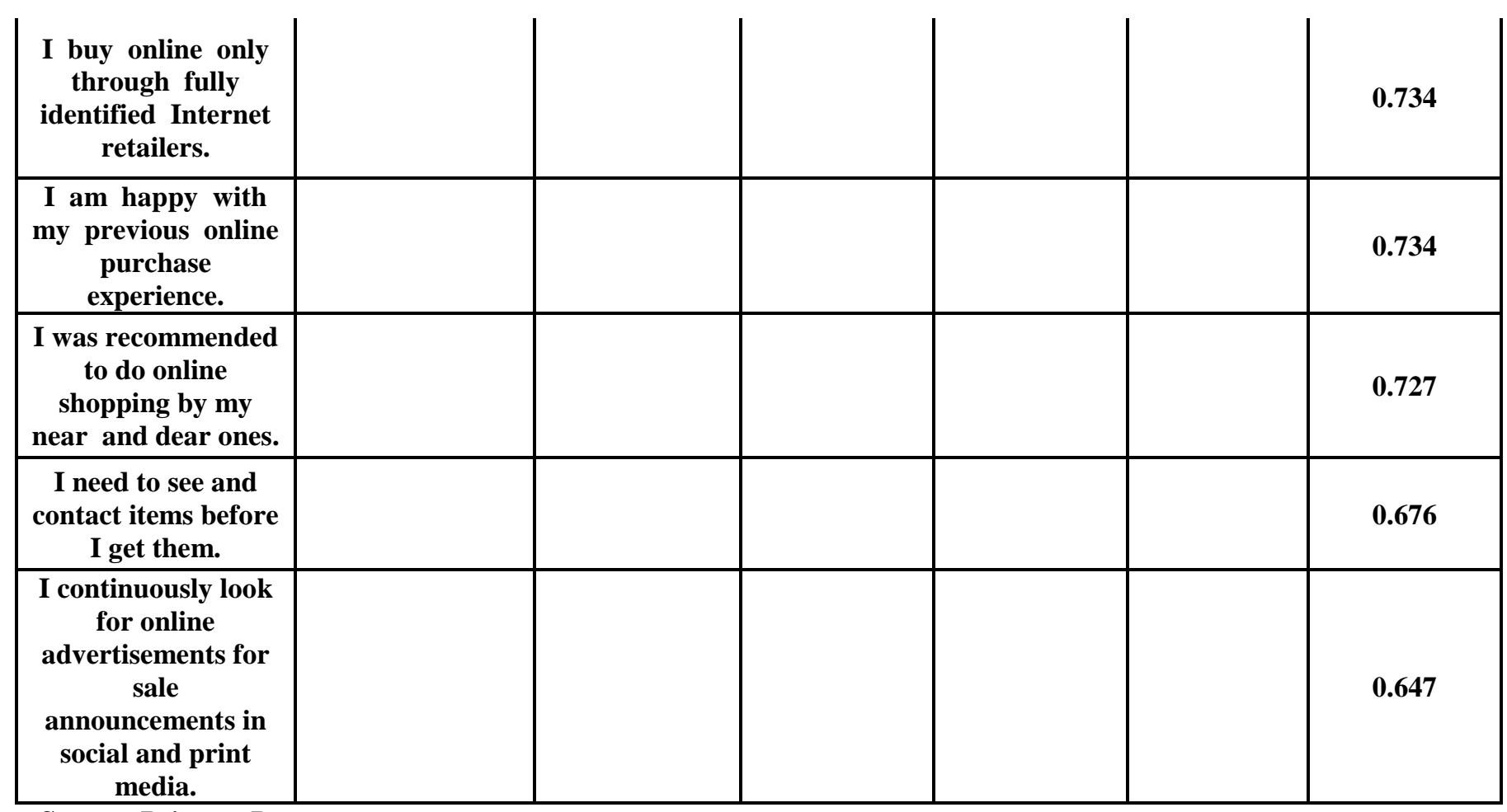

\section{Source: Primary Data}

\section{Factor 1: Convenience}

It consisted of 3 items related to the convenience caused by Online Shopping to the respondents.

Factor 2: Security and Privacy

It consisted of 2 items Security and Privacy of Personal and Financial information during Online Transaction.

\section{Factor 3: Product Related Factor}

It consisted of 6 items related to quality, variety of products, availability of Economical products and availability of discounts and offers online.

\section{Factor 4: Website related factor}

It consisted of 5 items related to availability of customer reviews, up-to-date product information on websites as well as website design.

\section{Factor 5: Service Related Factor}

It consisted of 8 items related to various services provided by online e-commerce websites such as cash on delivery option, option to swipe debit card, Non- serviceability of remote locations, product return policy etc.

Factor 6: Personal Factor

It consisted of 8 items related to individual's own perception towards online shopping.

\section{HYPOTHESIS TESTING}

H1: Explored Factors significantly impact the respondent's Online Purchasing Decision.

H1 a: Convenience Factor significantly impact the respondent's decision to purchase online.
Null Hypothesis: Convenience Factor do not significantly impact the respondent's decision to purchase online.

Since $p>0.05(0.186)$, the difference is non- significant. Thus, the null Hypothesis is rejected. Therefore, Convenience Factor significantly impacts Online Purchasing Decision.

H1 b: Security and privacy significantly impacts respondent's decision to purchase online.

Null Hypothesis: Security and Privacy do not significantly impact respondent's decision to purchase online.

Table 6- Security and Privacy Factor

\begin{tabular}{|c|c|c|}
\hline Security and Privacy Factor & F Value & p \\
\hline $\begin{array}{c}\text { Security of Personal and } \\
\text { Financial Information }\end{array}$ & 2.632 & $0.055^{*}$ \\
\hline Privacy is Assured & & \\
\hline
\end{tabular}

\section{Source: Primary Data}

Since $\mathrm{p}<0.05(0.055)$, the difference is significant. Thus, the null hypothesis is accepted which conveys that Security and Privacy do not significantly impact Online Purchasing Decision.

H1 c: Website Related factors significantly impacts respondent's decision to purchase online.

Null Hypothesis: Website related factors do not significantly impact Online Purchasing Decision. 
Table 7- Website factor

\begin{tabular}{|c|c|c|}
\hline Website Factor & F Value & p \\
\hline Downloading speed of E-Commerce sites is generally good. & $\mathbf{0 . 9 0 0}$ & $\mathbf{0 . 3 1 9}$ \\
\hline $\begin{array}{c}\text { It is easy to navigate through E-Commerce sites. } \\
\text { create image in my mind }\end{array}$ & & \\
\hline $\begin{array}{c}\text { Availability of Customer reviews and } \\
\text { recommendations on website. }\end{array}$ & & \\
\hline $\begin{array}{c}\text { Availability of sufficient amount and up-to- date } \\
\text { information on website. }\end{array}$ & & \\
\hline
\end{tabular}

Source: Primary Data

Since $p>0.05(0.900)$ the difference is non- significant. Thus, the null hypothesis is rejected which conveys that website related factors such as website design, downloading speed, looks and graphics of websites significantly impacts Online purchasing Decision..
H1 d: Product Related factors significantly impacts respondent's decision to purchase online.

Null Hypothesis: Product Related Factors do not significantly impact respondent's decision to purchase online.

Table-8 Product Related Factor

\begin{tabular}{|c|c|c|}
\hline Product Related Factor & F Value & $\mathbf{p}$ \\
\hline $\begin{array}{l}\text { Considerable difference in regular prices of products and } \\
\text { prices of Same products during period of sale on online } \\
\text { websites. }\end{array}$ & \multirow[t]{6}{*}{1.968} & \multirow[t]{6}{*}{$0.048^{*}$} \\
\hline Availability of discounts and offers online. & & \\
\hline Wider Product Selection & & \\
\hline Availability of economical products & & \\
\hline Better Quality of Products & & \\
\hline $\begin{array}{l}\text { There is considerable difference in prices of same products } \\
\text { across different websites. }\end{array}$ & & \\
\hline
\end{tabular}

\section{Source: Primary Data}

Since $p<0.05(0.048)$ the difference is significant. Thus, the null hypothesis accepted. Therefore, Product Related factors significantly impact Online Purchasing Decision.
Null Hypothesis: Service Related Factors do not significantly impact respondent's decision to purchase online.

H1 e: Service Related factors significantly impacts respondent's decision to purchase online.

Table 9- Service Related factor

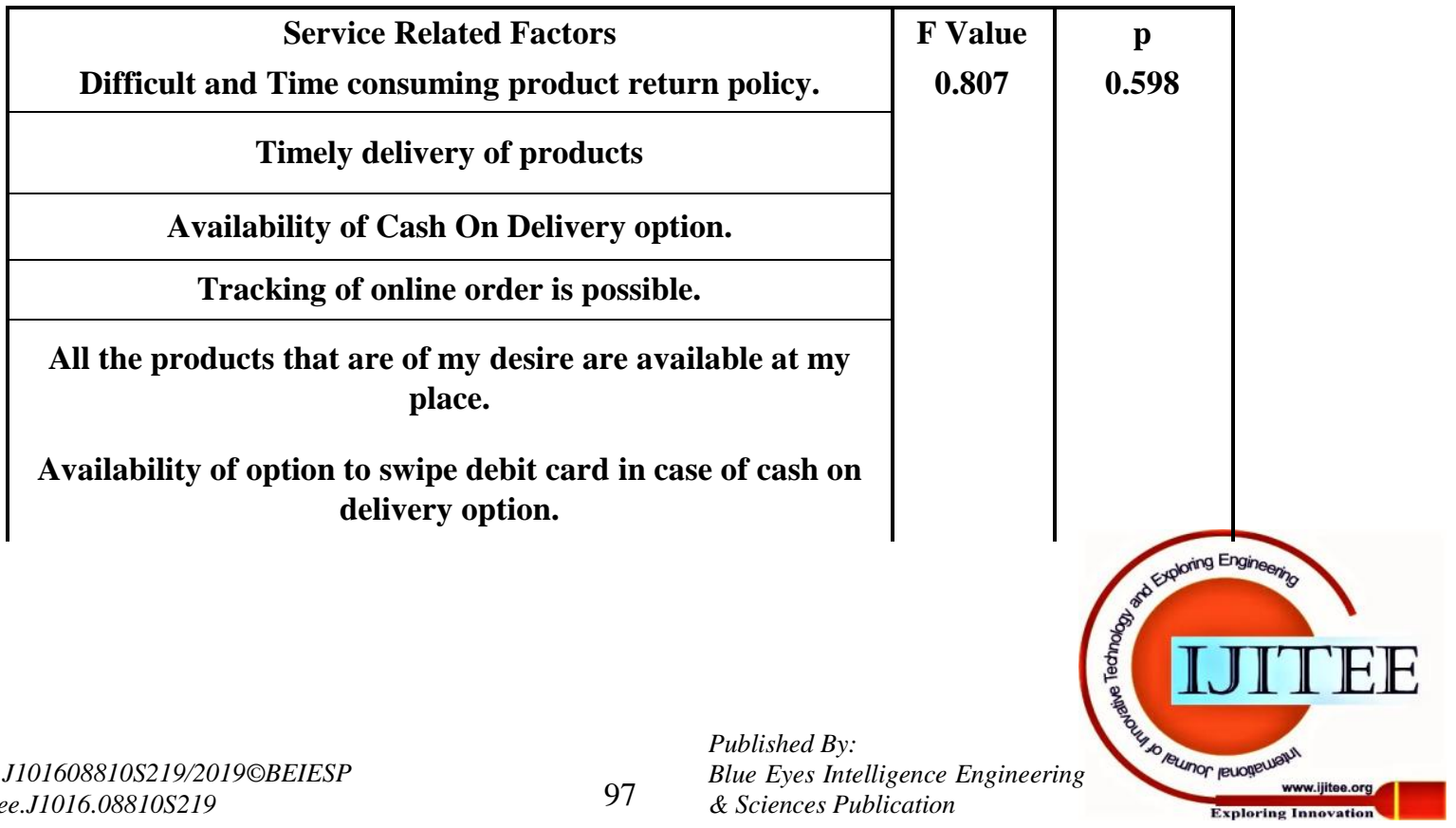




\begin{tabular}{|c||}
\hline Conformity of product as per order. \\
\hline Extra Hidden costs associated with modes of payment.
\end{tabular}

\section{Source: Primary Data}

Since $p>0.05(0.598)$ the difference is non- significant. Thus, the null hypothesis is rejected. Therefore, Service related factors significantly impact attitude towards online shopping.
H1 f: Personal Factors significantly impact respondent's decision to purchase online.

Null Hypothesis: Personal Factors do not significantly impact respondent's decision to purchase online.

Table 10: Personal Factor

\begin{tabular}{|c|c|c|}
\hline Personal Factors & \multirow{8}{*}{$\begin{array}{c}\text { F Value } \\
2.358\end{array}$} & \multirow{8}{*}{$\begin{array}{c}\text { p } \\
\text { 0.020* }\end{array}$} \\
\hline $\begin{array}{l}\text { I go through the variety of products offline before purchasing any } \\
\text { product online. }\end{array}$ & & \\
\hline I find it easy to shop what I want through Internet shopping. & & \\
\hline Online Shopping enhances my shopping effectiveness. & & \\
\hline I buy online only through fully identified Internet retailers. & & \\
\hline I am happy with my previous online purchase experience. & & \\
\hline I was recommended to do online shopping by my near and dear ones. & & \\
\hline $\begin{array}{l}\text { I continuously look for online advertisements for sale } \\
\text { announcements in social and print media. }\end{array}$ & & \\
\hline
\end{tabular}

\section{Source: Primary Data}

Since $p<0.05(0.020)$ the difference is significant. Thus, the null hypothesis is accepted. Therefore, Personal Factors do not significantly impact respondent's decision to purchase online.

\section{CONCLUSION}

It is obvious from the investigation that 32 odd variables obtained through rigorous literature survey were clustered into 6 factors that impact online purchasing decision. These components incorporate Convenience, Security and Privacy, Website related elements, Product related factor s, Personal factors and administration related variables. To the extent effect of investigated factors on online buying choice is concerned, we found that comfort factor, site related factor, administration related factor, item related factor have a critical effect on web based purchasing decision whereas personal factors and most importantly security and privacy factor are found not to have a critical impact on web based purchasing decision.

\section{LIMITATIONS AND SCOPE FOR FUTURE RESEARCH}

Despite the fact that the goals of the investigation were completely met, a couple of confinements have been distinguished over the span of this examination. To begin with, the present investigation concentrated on just chosen areas of Garhwal division of Uttrakhand.. This could constrain the speculation of discoveries. This makes a perfect chance to consider progressively differing statistic gatherings. Besides restricted factors were utilized in this investigation. Scientists can consider different elements that can likewise influence web based purchasing conduct. Further scientists can likewise direct research to analyze internet purchasing conduct with extraordinary reference to item classifications and brands just as with reference to explicit online business sites. In spite of the fact that example measure is adequate, it tends to be expanded by the future scientists. Further, this exploration is subject to common limitation of accuracy of response. Thus, in future researches different measures can be adopted to overcome them.

\section{REFERENCES}

1. Agarwal, S., \& Bhuvaneswari, V. (2016). Growing popularity of Online Shopping and its Impact on the Middle Class consumers With special reference to Uttarakhand ( India ). International Journal of Advance Research in Computer Science and Management Studies, $4(2), 35-44$.

2. Fortes, N., \& Rita, P. (2016). "Privacy concerns and online purchasing behavior: Towards an integrated model". European Research on Management and Business Economics, 22(3), 167-176.

3. Rahman, M. A., Islam, M. A., Esha, B. H., Sultana, N., \& Chakravorty, S. (2018). "Consumer buying behavior towards online shopping: An empirical study on Dhaka city, Bangladesh". Cogent Business \& Management, 5(1), 1-22. 
Consumer Online Purchase Decision and its Influencers in Uttrakhand: A Factor Analysis Method

4. Wang Miao \& Qu HongJian (2017). "Review of the Research on the Impact of Online Shopping Return Policy on Consumer Behavior" Journal of Administration Research,6(2),15-21.

5. Richa, Ranjan, Singh \& Kukreti, Ankur. (2018). "Effects of online shopping on consumer buying behavior International Journal of Creative Research Thoughts,6(2), 245-254.

6. Sawant Chetna \& Dr. Malviya Surendra (2014) "Perception of Youth towards Online Shopping" Altus Shodh Journal of Management and Commerce,May, 2014, 432-436.

7. Srivatsan, A., Vemulamanda, R. A., \& Venkatramana, V. (2018). "ECommerce In India - An Impetus To Growth". Journal of Management Research and Analysis, 5(1), 105-114.

8. Zhao, K. (2015). "Research on consumer online purchasing decision and its influencing factors: take taboo as example".

9. Harahap, Dedy \& Amanah, Dita. (2018). "Online Purchasing Decisions of College Students in Indonesia". International Journal of Latest Engineering Research and Applications, 3(10), 5-15.

10. Limpo, Lita \& Meryana. (2015). "Effect of Trust and Easy on Decision Online Purchase toward Special Fashion Products". International Journal of Science and Research (IJSR). 6(10), 6-391.

11. Katawetawaraks, Chayapa \& Wang, Cheng (2013). "Online Shopper Behavior: Influences of Online Shopping Decision” Asian Journal of Business Research, 1(2), 2011. 